\title{
Teachers' Teaching Experience and Educational Qualification as Correlates of Academic Performance of Students in Public Secondary Schools in Ekiti State, Nigeria
}

\author{
BOLARINWA Dapo Alonge; KOLAWOLE Adenike Olayinka \\ AYODELE Omowumi Victoria FAKUNLE Adewumi Francis ADETULE Oluwakemi \\ Faculty of Education, Department of Educational Management, PMB 5363, Ekiti State University, Ado-Ekiti, \\ Ekiti State, Nigeria
}

\begin{abstract}
The study examined the influence of teachers' teaching experience and educational qualification on academic performance of students in public secondary schools in Ekiti State, Nigeria. The purpose of the research is to find out the relationship between teachers' teaching experience, educational qualification and academic performance of students in public secondary schools. The descriptive research of the survey type was employed for the study. The study revealed that there was significant relationship between teachers' teaching experience, educational qualification and academic performance of students. The study had shown that teaching experience and educational qualification had influence on academic performance of students.
\end{abstract}

Keywords: Teachers' Teaching Experience, Educational Qualification, Academic Performance, Public Secondary Schools

DOI: $10.7176 / \mathrm{JEP} / 11-2-12$

Publication date: January $31^{\text {st }} 2020$

\section{Introduction}

Academic performance could be described as the scholastic standing of a student at a given examination. According to Omolayo (2009), the scholastic standing could be explained as the grades obtained in a course or group of courses taken. In collaboration with Omolayo (2009), Bello, Ibi and Bukar (2016) commented on the scholastic standing of students and argued that performance is a measure of output and that, the main outputs in education are expressed in terms of learning, that is, changes in knowledge, skills and attitudes of individuals as a result of their experiences with the school system. It has been observed that by the researchers that, performance of students in public secondary schools in Ekiti State is below expectation in the external examinations like the West African School Certificate Examination (WASCE) conducted by the West African Examinations Council (WAEC). According to Oluwole (2017), in 2014, West African School Certificate Examination result, Ekiti State public secondary schools were occupying $12^{\text {th }}$ position; in 2015 , they managed to clinch the $11^{\text {th }}$ position and in 2016, they were occupying $11^{\text {th }}$ position against $28^{\text {th }}$ position in 2013. In 2017 and 2018, Ekiti State public secondary schools occupied $11^{\text {th }}$ position respectively (Ekiti State Ministry of Education).

Teaching experience of a teacher can be measured based on the teacher's ability around comprehension and transformation of knowledge, concept to be imparted to learners. Teaching experience suggests that the most significant gains in students' performance will likely be realised when students receive instruction from teachers with good teaching experience. The underlying assumption is that, experience appears to promote competence. It appears, students attain higher levels of achievement when taught by more experienced teachers.

It has been observed by the researchers that the newly employed graduates are placed directly in Senior Secondary School classes with little or no experience to teach. This seems to be wrong because, they are supposed to be monitored and mentored by the experienced teachers. In essence, they are not to be teaching higher classes until when they have gathered enough expertise. The penetration of this system into teaching and learning seems to hinder proper coordination of the students. Hence, it appears, academic performance of students may be negatively affected.

According to Darling-Hammond (2000), teacher qualification combines both aspect of knowledge about the subject matter with learning and teaching. It appears, teachers who have the required qualifications to teach are not considered for employment and this might be because of the financial implications. It seems, an unqualified teacher cannot prepare students for external examinations like, the West African Senior School Certificate Examination.

Teaching experience includes participation in professional development activities geared towards equipping the teacher for better service delivery. Rodniques and Mckay (2010) defined experienced teacher as those who have taught for many years (five year and above) and are able to motivate students and hold their attention, know how they manage their lesson, classroom effectively and can change cause in the middle of a lesson. Boyd, Grossman, Lankford, Loab and Wyckoff (2008) believed that greater teaching experience will produce students with greater academic performance. 
Report by Darling-Hammond (2009) showed that on average, teacher with more than 10 years of experience are more effective than teachers with little or no experience but are not more effective than those with 5 years of experience. Akpo (2012) examined the impact of teacher-related variables on students in Junior Secondary School Certificate Mathematics results in Namibia, found out that, teaching experience was related to students' academic performance in JSC Mathematics. In the same vein, Ewetan and Ewetan (2015) in their study, teachers teaching experience and academic performance in Mathematics and English Language in public secondary schools in Ogun State, Nigeria found that teachers' teaching experience has significantly influenced students' academic performance in Mathematics and English Language.

In a study conducted by Abu and Fabunmi (2005) on the relationship among teachers variables and adult learners' academic performance in the part-time sub-degree programme of the University of Ibadan, Nigeria; it was discovered that there was a significant and positive relationship between teacher's qualification, age, years of teaching experience, teacher-learners ratio and adult learners' academic performance. Adeyemi (2008) examined teachers' teaching experience and students' learning outcomes in secondary schools in Ondo State, Nigeria and revealed that teachers' teaching experience was significantly related to students' learning outcomes.

According to Darling-Hammond (2000), teacher qualification combines both aspect of knowledge about the subject matter with learning and teaching. Akinsolu (2010) also investigated teachers' and students' academic performance in Nigerian secondary schools and its implications for planning found out that teachers' qualification, years of experience and teacher-student ratio were significantly related to students' academic performance. Ngware, Oketch, Mutisya and Abuya (2010) countered that teacher may be qualified and trained but still no effective learning may take place in the classroom.

\section{Methodology}

The descriptive research of the survey type was adopted for the study. The population of the study consisted of 203 secondary schools in Ekiti State, Nigeria (Source: Ekiti State Teaching Service Commission). There were 7,538 teachers in public secondary schools in Ekiti State, Nigeria as at the time of this study (Source: Ekiti State Teaching Service Commission). The sample for the study was 500 teachers.

Multistage sampling procedure was used for the study. The first stage involved simple random technique to select two local government areas from each of the three Senatorial Districts. The second stage involved the selection of 10 schools from the selected local government areas using stratified simple random sampling technique. The third and the last stage involved the selection of 10 teachers from each of of the 50 schools using purposive simple random sampling technique.

\section{Results}

The two hypotheses formulated for the study were tested as shown in tables 1 and 2.

Table 1: Test of relationship between teachers' teaching experience and academic performance of students

\begin{tabular}{|l|l|l|l|l|l|}
\hline Items & $\mathrm{N}$ & Mean & $\mathrm{SD}$ & $\mathrm{r}_{\text {cal }}$ & $\mathrm{r}_{\text {tab }}$ \\
\cline { 1 - 4 } Teacher's teaching experience & 500 & 101.96 & 3.75 & & \multirow{2}{*}{$0.793 *$} \\
\cline { 1 - 5 } Academic performance of students & 500 & 41.08 & 6.50 & 0.088 \\
\hline
\end{tabular}

$* \mathrm{p}<0.05$ (significant result)

Table 1 shows the relationship between teachers' teaching experience and academic performance of students. The result obtained from the analysis shows that the value of r-calculated (0.739) is greater than r-table value of (0.088). Therefore, the null hypothesis earlier formulated is rejected. This then means that there is significant positive relationship between teachers' teaching experience and academic performance of students.

Table 2: Test of relationship between teachers' qualification and academic performance of students

\begin{tabular}{|l|l|l|l|l|l|}
\hline Items & $\mathrm{N}$ & Mean & $\mathrm{SD}$ & $\mathrm{r}_{\text {cal }}$ & $\mathrm{r}_{\text {tab }}$ \\
\hline Teacher's teachers' qualification & 500 & 101.96 & 3.75 & & \multirow{2}{*}{$0.793^{*}$} \\
\cline { 1 - 4 } Academic performance of students & 500 & 41.08 & 6.50 & 0.088 \\
\hline
\end{tabular}
$* \mathrm{p}<0.05$ (significant result)

Table 2 shows the relationship between teachers' qualification and academic performance of students. The result obtained from the analysis shows that the value of $r$-calculated $(0.793)$ is greater than r-table value of $(0.088)$. Therefore, the null hypothesis earlier formulated is rejected. This then means that there is significant positive relationship between teachers' teaching qualification and academic performance of students.

\section{Discussion}

The study revealed that there was significant positive relationship influence of teachers' teaching experience on academic performance of students. This means that teaching experience of teachers will enhance the academic performance of students. This finding is in support of Boyd, Grossman, Lankford, Loab and Wyckoff (2008) who believed that greater teaching experience will produce students with greater academic performance; DarlingHammond (2009) who reported on average, teacher with more than 10 years of experience are more effective than 
teachers with little or no experience; and Ewetan and Ewetan (2015) who found out that teachers' teaching experience has significantly influenced students' academic performance in Mathematics and English Language.

The study also revealed that there was significant positive relationship influence of teachers' qualification on academic performance of students. This means that qualification of teachers will enhance the academic performance of students. This finding is in support of Akpo (2012) who found out that teacher educational qualification is related to students' academic performance in JSC Mathematics; Abu and Fabunmi (2005) who discovered a significant and positive relationship between teachers' qualification and adult learners ' academic performance.

\section{REFERENCES}

Abu, P.B. \& Fabunmi, M. (2005). The relationship among teacher variables and adult leaners' academic performance. International Journal of African American Studies, 4 (1), 12-20.

Adeyemi, T.O. (2008). Teachers' teaching experience and students' learning outcomes in secondary schools in Ondo State, Nigeria. Asian Journal of Information Technology, 7 (5), 201-209.

Akinsolu, O.A. (2010). Teachers and students' academic performance in Nigerian secondary schools: Implications for planning. Florida Journal of Educational Administration and Policy, 3 (2), 86-103.

Akpo, S.E. (2012). The impact of teacher-related variables on students' Junior Secondary Certificate Mathematics results in Namibia. PhD Thesis, School of Education, University of South Africa.

Bello, S., Ibi, M.B. \& Bukar, I.B. (2016). Principals' administrative styles and students' academic performance in Taraba State, Nigeria. Journal of Education and Practice, 7 (18), 62-69.

Boyd, D., Grossman, P., Lankford, H., Loab, S. \& Wyckoff, J. (2008). Overview of measuring effect sizes: The effect of measurement error. National Center for Analysis of Longitudinal Data in Education Research. Retrieved in January 16, 2012 from http://www.urban.org/uploadedPDF/1001264. Measuring effect sizes.pdf.

Darling-Hammond, L. (2000). Teacher quality and students' achievement. Education Policy Analysis Archives, 10 (36), 16-38.

Ewetan, T.O. \& Ewetan, O.O. (2015). Teachers' teaching experience and academic performance in Mathematics and English Language in public secondary schools in Ogun State, Nigeria. International Journal of Humanities, Social Sciences and Education, 2 (2), 123-134.

Ngware, M., Oketch, M., Mutisya, M. \& Abuya, B. (2010). Classroom observation study. A report on the quality and learning in primary schools in Kenya. Nairobi: APHRC.

Oluwole, J. (2017, September 3). Analysis: WAEC rating highlights dwindling fortunes of education in Southwest, Nigeria. Premium Times, Nigeria (online).

Omolayo, B. (2009). Effect of leadership styles on job related tension and psychological sense of community in work organisation: Case study of four organisations in Lagos State, Nigeria. Bangladesh Educational Journal of Social Sciences, 4(2), 133-157.

Rodniquez, A.G. \& Mckay, S. (2010). Professional development for professional teachers working with adult English Language learners. CAELA Network brief retrieved May 10, 2013 from www.cal.org 